This item was submitted to Loughborough's Research Repository by the author.

Items in Figshare are protected by copyright, with all rights reserved, unless otherwise indicated.

\title{
A global sense of flow?
}

PLEASE CITE THE PUBLISHED VERSION

http://dx.doi.org/10.1111/j.1475-4762.2008.840_3.x

\section{PUBLISHER}

(c) The Authors. Journal compilation (c) Royal Geographical Society (with The Institute of British Geographers), published by Blackwell Publishing

\section{VERSION}

AM (Accepted Manuscript)

\section{LICENCE}

CC BY-NC-ND 4.0

\section{REPOSITORY RECORD}

Taylor, Peter J., Michael Hoyler, Kathryn Pain, and John Harrison. 2019. “A Global Sense of Flow?”. figshare. https://hdl.handle.net/2134/7396. 
This item was submitted to Loughborough's Institutional Repository (https://dspace.lboro.ac.uk/) by the author and is made available under the following Creative Commons Licence conditions.

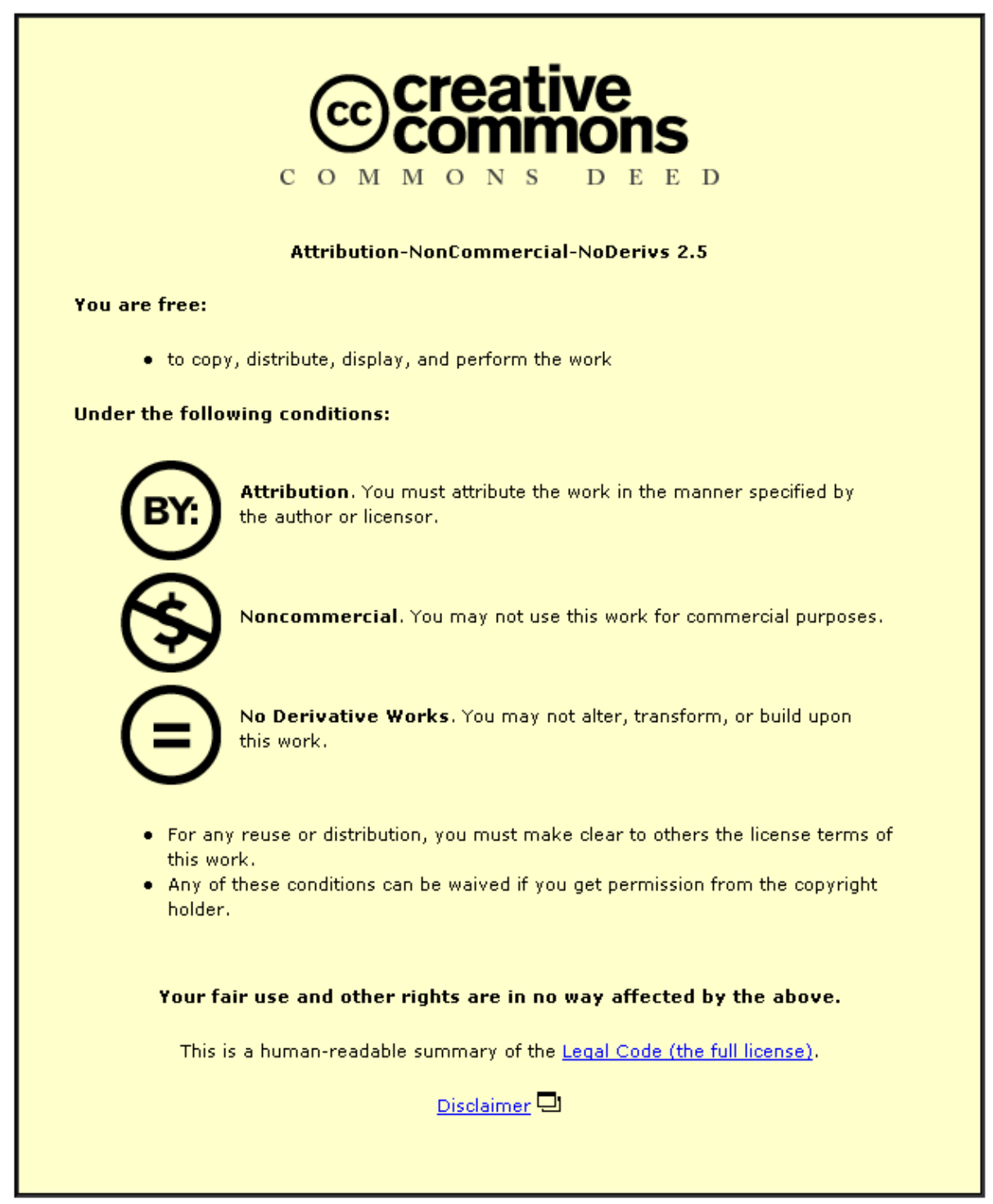

For the full text of this licence, please go to: http://creativecommons.org/licenses/by-nc-nd/2.5/ 


\section{A global sense of flow?}

Contribution to Book Review Forum on:

World City by Doreen Massey

Cambridge: Polity Press, 2007, 262 pp, £14.99 paperback

ISBN 978-0-7456-4060-0

Peter Taylor, Michael Hoyler, Kathy Pain and John Harrison

Globalization and World Cities Research Network

Loughborough University

Doreen Massey has made many contributions to geography over the years, but one feature stands out in her research: she has brought region and place centre stage in developing her radical/emancipatory arguments. This powerful strain in her thinking can be said to culminate in her in-depth treatment of contemporary London as a world city. Although we are told that the book is 'centred on London', she qualifies this by saying 'it is not really only about London', it is a set of ideas that 'arises from London' (p. 12). This is because to understand London you have to understand what goes on beyond London:

$[P]$ ower relations of all sorts ... run around the globe and ... link the fate of other places to what is done in London. This is the other geography [of London], the external geography if you like, of a global sense of place. (p. 7)

At first viewing, this position is exemplary; it certainly appears to chime well with our focus on inter-city relations in contemporary globalization. But a little further thought shows this not to be the case: Massey's global sense of place is in danger of understating the global.

Here, we can employ Allen's (1999) insightful comparison of Sassen's (1991) and Castells' (1996) treatment of 'cities in globalization' as a heuristic device to engage with Massey. According to Allen: 
Where the two accounts radically diverge $\ldots$ is over the source of the economic power and influence of global cities. For Castells, power is concentrated in the networked space of flows, whereas for Sassen it is concentrated in those groups who exercise the command-and-control functions embedded in global cities. $(1999,202)$

Massey makes numerous references to Sassen's research - but not Castells' (despite her use of the terms 'space of flows' and 'a world of flows': pp. 54, 154). This leads us to suspect that, like Sassen, Massey is thinking within a 'spaces of places' framework. For her, places - and London in particular - are porous and fuzzy, but there is always a sense of inside/outside in the way London is treated as either a source of global neo-liberalism or a point of resistance to it. This does not prevent the identification of the 'disjunction' between 'territorialised politics' and 'another geography of flows and interconnections' ( $p .14$ ) which so debilitates contemporary urban radical politics through being 'corralled, and thereby constrained' (p. 151), but it does limit how the 'flows and interconnections' are incorporated into both the geography and its resultant politics in order to confront the disjuncture.

We can see Massey's space of place thinking when she promotes a 'foreign politics' for local authorities (p. 184); when she focuses on 'trajectories' of cities in regions ( $p .157$ ); and when she calls for a 'geography of responsibility' (p. 179). Such thinking is particularly central to her key argument on the successful strategy of synecdoche through which the City and its interests are deemed to be the interests of London. This representation of the whole by a part means that policy is all about London as a global city at the expense of the rest of London (and the UK). This is an example of what is happening in London having resonances in cities across the world. Massey also refers to Robinson's (2002) idea of 'ordinary cities' to banish the concept of 'world city', but this is a classic error of emphasis on place rather than process. Following Jacobs (1969) and Castells (1996), cities can be seen as process, an internal clustering and external networking process. This 'city-ness' is an extraordinary generic force that has expanded economies across the times and spaces of 
civilization, taking the form of 'world city-ness', the linking of business interests across the world, in the present. The major advantage of thinking in these terms is that unlike place, processes can occur simultaneously in the same location.

Thus London is a world city - it experiences this process more intensively than many other cities - but this is one of many processes that are London-asprocess in the early twenty-first century. For radical politics, it is not a matter of un-naming it and hoping this lessens its power, rather it is necessary to understand world city-ness to better confront it. And this cannot be done one city at a time. This is the point of Castells' city process; it is a network mechanism. The network is manifest as a triple level network: there is a subnodal level which is business firms as the agents (network makers), a nodal level of the cities, and a network level of the network of cities in the world economy (Taylor 2004). Hence, it is not enough to argue, as Massey does, that 'the economy of a place is a product not only of internal interactions but also of relations with elsewhere' (p. 20). We need to know about the work done by American, Japanese, German, French and Spanish banks in London as part of their global strategies of financial work. We need to know how Clifford Chance became the world's leading law firm not just in its London base but through its global network of law offices. Put simply, the power of world city-ness is in the networks not the places.

Such network thinking requires empirical study to depict process patterns, which is where GaWC contributes (Beaverstock et al. 2001; Taylor 2004; Taylor and Aranya 2006). Drawing on such work, the big surprise is the lack of attention given to New York in Massey's attempt to understand London as a world city. Measuring power through networks, these two cities are the twin peaks: the NYLON dyad is 'Main Street, World Economy' (Taylor et al. 2002). Note that the unit of interest within the network is relational, city dyads. In 'space of places' terms, such city pairs are seen hierarchically as being in competition, but networks are inherently cooperative, they exist on mutuality. To take another dyad, London and Frankfurt's world city-ness is essentially cooperative despite the common assumption that they compete (Beaverstock 
et al. 2001). Although the 'neoliberal mantra' is that 'cities ... must compete with each other' (p. 200), it is surely important to know that this is not the way businesses are using cities in the world city process. Therefore a 'progressive politics' cannot simply promote cooperation among cities when this is happening already through the agency of their 'opponents'! This is particularly important for the UK's other cities, which are also underrepresented in this 'external geography' of London. For Massey, London and the South East are pitted against 'the regions' (never Manchester and the North West, Newcastle and the North East, Birmingham and the West Midlands, etc.) so that citydyads are not to the fore. Massey does suggest these regions have 'a colonial relationship' (p. 107) with London and their cities have 'relatively little relational power' (p. 170), but these assertions are made without empirical knowledge of current network patterns: actually, under globalization, these city-economies appear to be improving through new business networks (Taylor and Aranya 2006) and spatial initiatives like the 'Northern Way' (Harrison 2007; Taylor et al. 2007).

It is the politics of Massey's world city that is, perhaps, most fascinating in her argument. As previously noted, the dilemma of place politics in a network world is recognised; Ken Livingstone's attempt to rectify the 'London deficit' 'a radical mayor' in 'a minefield' (p. 145) - is a wonderful example. Massey's final chapter is on the meaning of her argument for practical politics and it is both the most thoughtful and original chapter and also the most unsatisfactory. The paradox is a function of the subject matter - 'A politics of place beyond place'. There are some dyads here such as London-Caracas (surely the future is not going to be inter-city barter!?) but there is no sense of overall political strategy. The ideas don't fit together as a political way forward. Previously Massey (p. 154) had quoted Paul Gilroy's notion of 'cosmopolitan solidarity from below and afar'; we have lots of experience of mobilization 'from below' through spaces of place but little mobilization 'from afar' through spaces of flows. And this is the rub: imagining such a project through our modern political lenses appears to be all but impossible. 
To conclude, we return to Allen $(1999,203)$ and his assertion that the question' is 'whether the networks themselves "generate" cities as sites of power through their interconnections or whether cities "run" the networks through their concentration of resources and expertise'. He quickly retracts the crispness of the distinction saying that he 'probably overstates the differences' (p. 203) and we shall do the same here. There is much in Massey's arguments that is compatible with 'networks of cities' although her primary thrust is explicitly place-centred. The approaches are best viewed as complementary, as alternative formulations bringing relational theory into geography. For Massey (p. 171), there is a need 'to challenge the nature of the local place, its role within the wider power-geometries'; all we are adding is that for this to be at all achievable, we need to engage practically with global networks. Massey's alternative geography is a regional one, implying territorial reform; ours is a network geography, a revolution only slowly being invented.

\section{References}

Allen J 1999 Cities of power and influence: settled formations in: Allen J, Massey D and Pryke M eds Unsettling cities: movement/settlement Routledge, London 181-218

Beaverstock J V, Hoyler M, Pain K and Taylor P J 2001 Comparing London and Frankfurt as world cities: a relational study of contemporary urban change Anglo-German Foundation for the Study of Industrial Society, London

Castells M 1996 The rise of the network society Blackwell, Oxford

Harrison J 2007 From competitive regions to competitive city-regions: a new orthodoxy, but some old mistakes Journal of Economic Geography 7 311-332

Jacobs J 1969 The economy of cities Vintage, New York 
Robinson J 2002 Global and world cities: a view from off the map International Journal of Urban and Regional Research 26 531-54

Sassen S 1991 The global city Princeton University Press, Princeton, NJ

Taylor P J 2004 World city network: a global urban analysis Routledge, London

Taylor P J and Aranya R 2006 Connectivity and city revival Town \& Country Planning November 2006 309-14

Taylor P J, Hoyler M, Evans and Harrison J 2007 Balancing London? A preliminary investigation of the 'Core Cities' and 'Northern Way' spatial policy initiatives using multi-city corporate and commercial law firms GaWC Research Bulletin 224 (http://www.lboro.ac.uk/gawc/rb/rb224.html). Accessed 22 February 2008

Taylor P J, Walker D R F, Catalano G and Hoyler M 2002 Diversity and power in the world city network Cities 19 231-241 